\title{
PENGARUH PERBEDAAN JENIS KELAMIN TERHADAP FREKUENSI NAFAS, DENYUT JANTUNG, SUHU SHANK, DAN SUHU REKTAL AYAM KUB
}

\author{
Effect of Sex Differences on Breath Frequency, Heart Rate, Shank Temperature, and Rectal \\ Temperature of KUB Chicken
}

\author{
Lukman Hakim, Khaira Nova, Purnama Edy Santosa, Rr Riyanti \\ Jurusan Peternakan, Fakultas Pertanian, Universitas Lampung \\ Jalan Prof. Dr. Soemantri Brodjonegoro No. 1 Bandar Lampung, Lampung 35145 \\ e-mail: Lukman15hakim@gmail.com
}

\begin{abstract}
This study aimed to determine the effect of sex differences on the physiology of chickens including respiratory frequency, heart rate, shank temperature, and rectal temperature of KUB chickens. The research was conducted on 10--16 August 2017 at Cage Integrated Field Laboratory, Faculty of Agriculture, University of Lampung. This study used 50 chickens (25 males and 25 females) aged 13 weeks with an average weight of $850 \mathrm{~g}$. Data were collected after measuring the temperature and humidity at 08.00-17.00 for 3 consecutive days to determine the extreme temperature of the environment. The variables in this study were respiratory rate, heart rate, shank temperature, and rectal temperature of KUB chickens at extreme temperatures. The results were analyzed using the t-test at the 5\% significance level. The t-test results showed that the sex of KUB chickens had no significant effect on respiratory frequency, heart rate, shank temperature, and rectal temperature.
\end{abstract}

Key words : Chicken physiological, KUB chicken, Sex type

\begin{abstract}
ABSTRAK
Penelitian ini bertujuan untuk mengetahui pengaruh perbedaan jenis kelamin terhadap fisiologis ayam meliputi frekuensi nafas, denyut jantung, suhu shank, dan suhu rektal ayam KUB. Penelitian telah dilakukan pada 10--16 Agustus 2017 di Kandang Laboratorium Lapang Terpadu, Fakultas Pertanian, Universitas Lampung. Penelitian ini menggunakan 50 ekor ayam ( 25 ekor jantan dan 25 ekor betina) berumur 13 minggu dengan bobot rata-rata 850 g. Pengambilan data dilakukan setelah pengukuran suhu dan kelembaban pukul 08.00--17.00 WIB selama 3 hari berturut untuk menentukan suhu ekstrim lingkungan. Peubah pada penelitian ini adalah frekuensi nafas, denyut jantung, suhu shank, dan suhu rektal ayam KUB di suhu ekstrim. Hasil penelitian dianalisis menggunakan uji t pada taraf nyata 5\%. Hasil uji t menunjukkan bahwa jenis kelamin ayam KUB tidak berpengaruh nyata terhadap frekuensi nafas, denyut jantung, suhu shank, dan suhu rektal.
\end{abstract}

Kata kunci: ayam KUB, Fisiologis ayam, Jenis kelamin

\section{PENDAHULUAN}

Perkembangan teknologi dan tingkat pengetahuan masyarakat di Indonesia, meningkatkan pula kesadaran akan pentingnya mengonsumsi protein hewani. Protein hewani dapat diperoleh dari mengonsumsi daging, telur, dan susu. Salah satu penyumbang protein hewani adalah ayam. Ayam di Indonesia yang dikenal ada dua jenis yaitu ayam ras dan ayam bukan ras (Buras) atau ayam kampung.

Ayam kampung merupakan ayam yang sangat dikenal oleh masyarakat Indonesia dan banyak dibudidayakan di pedesaan karena daya tahan dan tingkat adaptasi yang baik pada suhu ekstrim. Salah satunya ayam Kampung Unggul Balitnak (KUB).

Ayam KUB merupakan pengembangan ayam kampung dengan teknologi pembibitan oleh Badan Penelitian Ternak (Balitnak), Ciawi Bogor. Pemeliharan ayam ini dilakukan secara intensif (ternak dikandangkan). Kegiatan mengandangkan ternak merupakan suatu tindakan yang secara fisiologis akan mengubah cara kerja dan mekanisme alami ternak dalam mengatur hidupnya. Selain proses pemeliharaan, perbedaan 
jenis kelamin juga mempengaruhi fisiologis pada ayam.

Menurut Gous (2010) dan Ozkan et al. (2010), perbedaan jenis kelamin ayam pedaging dapat memengaruhi konsumsi pakan, bobot badan akhir, dan fisiologis ternak. Untuk itu perlu diteliti untuk mengetahui perbedaan jenis kelamin terhadap fisiologis ayam KUB meliputi; frekuensi nafas, denyut jantung, suhu shank, dan suhu rektal.

\section{MATERI DAN METODE}

\section{Waktu dan Tempat}

Penelitian ini dilaksanakan pada $10-16$ Agustus 2017, bertempat di Kandang, Laboratorium Lapang Terpadu, Fakultas Pertanian, Universitas Lampung.

\section{Materi}

Bahan yang digunakan pada penelitian ini yaitu, 50 ekor ayam KUB (25 ekor jantan dan 25 ekor betina) umur 13 minggu dengan rata-rata bobot tubuh $850 \mathrm{~g}$.

Alat yang digunakan pada penelitian ini antara lain: kandang postal, petak kandang dari waring, counter, stetoskop, termometer, stopwatch, thermohygrometer, dan alat tulis.

\section{Metode \\ Perlakuan}

Penelitian ini menggunakan ayam berumur 13 minggu untuk melihat sifat fisiologisnya, meliputi frekuensi nafas, denyut jantung, suhu shank, dan suhu rektal ayam KUB. Sebelum pengambilan data diukur suhu dan kelembapannya untuk mengetahui suhu ekstrim lingkungan.

\section{Peubah yang Diamati}

Peubah yang diamati dalam penelitian ini adalah frekuensi nafas, denyut jantung, suhu shank, dan suhu rektal ayam KUB.

\section{Pengukuran Peubah}

Frekuensi pernapasan dihitung dengan menghitung pergerakan thorax selama 30 detik (Yousef, 1985). Pengambilan data ini dilakukan pada minggu ke 13 pemeliharaan, saat suhu kritis $34^{\circ} \mathrm{C}$.

Frekuensi denyut jantung diperoleh dengan cara menempelkan stetoskop pada bagian dada kiri unggas, sehingga terdengar denyut jantungnya selama satu menit (Hartono et, al., 2002). Pengambilan data ini dilakukan pada minggu ke 13 pemeliharaan, saat suhu kritis $34^{\circ} \mathrm{C}$.
Suhu shank diukur dengan cara menempelkan termometer rektal pada kulit shank selama \pm 2 menit ( zhou dan yamamoto, 2010). Pengambilan data ini dilakukan pada minggu ke 13 pemeliharaan, saat suhu kritis $34^{\circ} \mathrm{C}$.

Suhu rektal diperoleh dengan cara memasukkan thermometer digital ke dalam rektal unggas (Hartono et, al., 2002). Termometer dimasukkan kedalam rektal sedalam $\pm 1 / 3$ bagian termometer dan hingga berbunyi dan diulangi sebanyak 3 kali. Pengambilan data ini dilakukan pada minggu ke 13 pemeliharaan, saat suhu kritis $34^{\circ} \mathrm{C}$.

\section{Analisis Data \\ Data yang diperoleh dianalisis menggunakan Uji-t pada taraf nyata 5\%.}

\section{HASIL DAN PEMBAHASAN}

\section{Pengaruh Jenis Kelamin terhadap Frekuensi Nafas}

Pada Tabel 1 uji t menunjukkan bahwa jenis kelamin jantan dan betina tidak berpengaruh nyata terhadap frekuensi nafas. Hal ini diduga karena kondisi lingkungan (suhu dan kelembaban), umur, dan pakan yang dikonsumsi ayam sama. Pada kondisi lingkungan ekstrim dengan suhu $34^{\circ} \mathrm{C}$ ayam umur 13 minggu sudah mampu beradaptasi dengan lingkungan.

Pada suhu lingkungan ekstrim ayam cenderung mengalami stress, karena kesulitan membuang panas tubuhnya ke lingkungan (Cooper dan Wasburn, 1998). Tingginya suhu lingkungan juga akan memengaruhi tingkah laku ternak serta fungsi beberapa organ tubuh seperti jantung dan alat pernafasan (Sohail et al., 2010). Virden dan Kidd (2009) mengatakan bahwa ketika ternak mengalami stres karena suhu lingkungan ekstrim, sistem neurogenik langsung diaktifkan, ditandai dengan peningkatan tekanan darah, otot, sensitivitas saraf, gula darah dan respirasi. Hal tersebut akan menyebabkan panting, tetapi diduga ayam tidak langsung panting karena panas dalam tubuh sudah dapat diatasi dengan melakukan konveksi dan konduksi. Konveksi terjadi melalui aliran udara dari jengger, pial, wajah, kaki, jari-jari, leher, tubuh dan sayap (Yahav et al., 2005). Konduksi terjadi dengan menyalurkan panas dari tubuh ke permukaan benda, misalnya litter, lantai atau dinding kandang (Hilman et al., 1985). 
Tabel 1. Rata - rata frekuensi nafas, denyutjantung, suhu shank, dan suhu rektal ayam KUB

\begin{tabular}{ccccc}
\hline \multirow{2}{*}{ Peubah } & \multicolumn{4}{c}{ Variabel } \\
\cline { 2 - 5 } & $\mathrm{N}$ & Jantan & Betina & P - Value \\
\hline $\begin{array}{c}\text { Frekuensi nafas } \\
\text { (kali/menit) }\end{array}$ & $50(\mathrm{~J} 25 ; \mathrm{B} 25)$ & $29.12 \pm 5.94$ & $30.24 \pm 5.04$ & 0.98 \\
$\begin{array}{c}\text { Denyut jantung } \\
\text { (kali/menit) }\end{array}$ & $50(\mathrm{~J}$ 25; B 25) & $307.04 \pm 43.22$ & $300.96 \pm 24.61$ & 0.55 \\
Suhu shank $\left({ }^{\circ} \mathrm{C}\right)$ & $50(\mathrm{~J}$ 25; B 25) & $36.41 \pm 0.89$ & $37.27 \pm 1.31$ & 0.16 \\
Suhu rektal $\left({ }^{\circ} \mathrm{C}\right)$ & $50(\mathrm{~J}$ 25; B 25) & $42.06 \pm 0.38$ & $42.04 \pm 0.29$ & 0.48 \\
\hline
\end{tabular}

Keterangan : Jantan dan betina adalah jenis kelamin ayam KUB

Seharusnya ayam betina frekunsi nafasnya lebih banyak dibandingkan dengan ayam jantan, hal ini dikarenakan mekanisme peranan hormon-hormon reproduksi primer pada ayam betina lebih banyak dibandingkan pada ayam jantan. Menurut Suharyati et al., (2017), hormon berfungsi sebagai pembangkit aktifitas fisiologi dan metabolisme yang penyebarannya diangkut melalui darah dan diterima pada sel target karena adanya reseptor. Aktifitas reproduksi ayam betina yang menyebabkan meningkatnya frekuensi nafas yaitu proses pembentukan telur. Proses pembentukan telur memerlukan waktu 23-26 jam dari proses pembentukan kuning telur (yolk) hingga terbentuk telur yang siap dikeluarkan (Fadilah dan Fathkuroji, 2013).

Hasil penelitian ini menunjukkan ratarata frekuensi nafas ayam KUB betina lebih tinggi dibandingkan dengan ayam KUB jantan, tetapi tidak terdapat perbedaan nyata dengan signifikansi $\mathrm{P}>0,05$, artinya faktor suhu lingkungan lebih mempengaruhi. Frekuensi nafas ayam KUB jantan dan betina pada suhu lingkungan ekstrim lebih tinggi dibandingkan dengan frekuensi nafas ayam pada suhu normal, yaitu berkisar 18--23 kali per menit (Frandzon, 1993). Frekuensi nafas ayam KUB jantan dan betina pada suhu ekstrim sejalan dengan peryataan Yousef (1985) yang mengatakan bahwa frekuensi nafas merupakan salah satu respon fisiologis yang digunakan untuk mengatasi stres itu sendiri.

\section{Pengaruh Jenis Kelamin terhadap Denyut Jantung}

Pada Tabel 1 uji t menunjukkan bahwa jenis kelamin tidak berpengaruh nyata pada denyut jantung ayam KUB. Hal ini diduga karena ayam jantan dan betina mengalami respon yang sama terhadap suhu lingkungan, sehingga tidak menyebabkan perbedaan denyut jantung. Selain itu, ayam yang sudah berumur13 minggu sudah mampu beradaptasi di lingkungan tersebut.

Cogburn dan Harrison (1980) mengatakan bahwa panas pada tubuh unggas yang umumnya dipengaruhi suhu ekstrim dibawa oleh darah yang mengalir melewati mukosa saluran pernafasan dan dibuang melalui penguapan air. Setelah itu darah meninggalkan saluran pernafasan masuk ke vena yang lebih dingin kemudian menuju jantung dan selanjutnya dipompakan ke seluruh tubuh sehingga terjadi penurunan suhu.

Semakin panas lingkungan maka suhu tubuh unggas semakin tinggi. Tingginya suhu tubuh unggas menyebabkan panas yang dibawa darah menuju jantung semakin banyak. Usaha ini merupakan salah satu cara menyebarkan panas tubuh atau pendinginan ke seluruh tubuh. McDowell (1972) menyebutkan bahwa usaha ini berkaitan dengan peningkatan denyut jantung.

Hasil penelitian menunjukkan bahwa rata-rata denyut jantung ayam KUB jantan dan betina lebih tinggi dibandingkan dengan denyut jantung ayam normal berkisar 150--304 kali per menit (Swenson, 1997). Hal ini diduga karena ayam KUB jantan dan betina pada penelitian lebih banyak bergerak.

Pengaruh Jenis Kelamin terhadap Suhu Shank Pada Tabel 1 uji t menunjukkan bahwa jenis kelamin jantan dan betina tidak berpengaruh nyata terhadap suhu shank. Hal ini diduga karena kondisi lingkungan (suhu dan kelembaban), umur, dan aktivitas ayam yang sama. Pada kondisi lingkungan ekstrim, dengan suhu $34^{\circ} \mathrm{C}$ diduga ayam umur 13 minggu sudah mampu beradaptasi dengan lingkungannya.

Pada suhu lingkungan ekstrim ayam cenderung mengalami stres, karena kesulitan membuang panas tubuhnya ke lingkungan (Cooper dan Wasburn, 1998). Sebelum panas dikeluarkan, panas mengalir melalui pembuluhpembuluh darah kecil dan berkumpul di shank, 
sehingga menyebabkan suhu shank meningkat. Shank adalah salah satu organ yang memiliki banyak pembuluh darah kecil, sehingga panas dapat dilepaskan ke lingkungan. Pelepasan panas ini adalah salah satu respon dari rangsangan syaraf symphatetik untuk mempertahankan suhu tubuh ternak melalui shank

(Yanagi et al., 2002; Mutaf et al., 2008; dan Yahav et al., 2008). Dawson dan Whittow (2000) menyatakan bahwa panas dapat dievaporasikan melalui pembuluh-pembuluh darah kecil yang tersebar di permukaan tubuh ayam. Sehingga tingginya suhu shank ini karena shank merupakan organ yang efektif untuk mengevaporasikan panas tubuh ayam (Paliadi, 2015).

Hasil penelitian menunjukkan bahwa suhu shank pada ayam KUB jantan dan betina lebih tinggi dari suhu shank ayam fase grower $27,6^{\circ} \mathrm{C}$ (Mushawwir dan Latipudin, 2011). Hal ini disebabkan oleh tingginya suhu lingkungan pemeliharaan ayam KUB. Untuk menjaga suhu rektal ayam tetap pada kondisi normal, panas yang berlebih harus dikeluarkan. Salah satunya dengan cara evaporasi. Shank merupakan organ yang efektif untuk mengevaporasikan panas tubuh ayam (Paliadi, 2015) karena memiliki pembuluh darah kecil yang menyebar. Paliadi (2015) juga menyatakan bahwa sebelum panas dikeluarkan, panas mengalir melalui pembuluh-pembuluh darah kecil dan berkumpul di shank, inilah yang menyebabkan suhu shank pada penelitian lebih tinggi dari suhu shank normal.

\section{Pengaruh Jenis Kelamin terhadap Suhu Rektal}

Pada Tabel 1 uji t menunjukkan bahwa jenis kelamin jantan dan betina tidak berpengaruh nyata terhadap suhu rektal. Hal ini diduga karena kondisi lingkungan (suhu dan kelembaban), aktivitas, dan pakan yang dikonsumsi ayam sama. Pada kondisi lingkungan ekstrim, dengan suhu $34^{\circ} \mathrm{C}$ diduga ayam umur 13 minggu sudah mampu beradaptasi dengan lingkungannya, baik suhu dan juga pakan yang diberikan.

Ayam merupakan hewan homeoterm (berdarah panas) yang mempertahankan suhu tubuhnya pada kondisi normal dengan cara thermoregulasi. Thermoregulasi merupakan hasil kerja beberapa organ tubuh yang saling berhubungan (Bilgh, 1985). Pada tubuh unggas terdapat beberapa organ tubuh yang dapat membantu proses penurunan panas. Salah satunya organ shank yang berperan dalam proses pelepasan panas rektal ayam (Paliadi, 2015). Tingginya suhu rektal ayam pada hasil penelitian karena ayam mengalami stress panas yang disebabkan oleh tingginya suhu lingkungan pemeliharaan. Ayam beradaptasi dengan mekanisme thermoregulasi agar dapat mempertahankan suhu tubuhnya sehingga panas yang dilepaskan sebanding dengan panas yang diterima dan yang dibentuk dalam tubuh ayam (Lin et al., 2005) melalui shank, panting, atau cara lainnya.

Hasil penelitian menunjukkan rata-rata suhu rektal ayam KUB jantan dan betina lebih tinggi dari suhu normal ayam umumnya berkisar 40,5--41,5 ${ }^{\circ} \mathrm{C}$ (Etches et al., 2008). Hal ini disebabkan oleh suhu lingkungan pemeliharaan ayam yang lebih tinggi dibandingkan dengan yang dibutuhkan oleh ayam itu sendiri atau suhu yang baik untuk pemeliharaan, yakni berkisar 21$-27^{\circ} \mathrm{C}$ (Priyatno, 2004). Tamzil et al. (2013) menyatakan bahwa pemeliharaan pada suhu kandang yang mencapai $40^{\circ} \mathrm{C}$ dan dibiarkan selama 1,5 jam akan meningkatkan suhu rektal diikuti dengan peningkatan frekuensi panting, konsumsi air minum, serta penurunan konsumi pakan.

\section{SIMPULAN DAN SARAN}

\section{Simpulan}

Hasil penelitian menunjukkan bahwa jenis kelamin tidak berpengaruh nyata pada frekuensi nafas, denyut jantung, suhu shank, dan suhu rektal ayam KUB.

\section{Saran}

Saran untuk penelitian selanjutnya, yaitu untuk menambah faktor pengaruh lain untuk pengamatan fisiologis, selain jenis kelamin.

\section{DAFTAR PUSTAKA}

Bligh. 1985. Thermal Physiology. in: Yousef, M. K. Stress Physioloy in Livestock. Vol. III. CRC. Florida.

Cogburn L. A. and P. C. Harrison. 1980. Adrenal, Thyroid, and Rectal

Temperature Responses of Pinealectomized Cockerels to Different Ambient Temperatures. Department of Animal Science. University of Illinois. Urbana. Illinois 61801.

Cooper, M.A. and K. W. Washburn. 1998. The relationships of body temperature to weight gain, feed consumption, and feed utilization in broilers under heat stress. Poult. Sci. 77:237--242.

Dawson, W.R. and G.C. Whittow. 2000. Regulation of Body Temperature. In Whittow GC, editor. Sturkie's Avian 
Physiology. Ed 5th. San Diego: Academic Press.

Etches, R. J, T. M. John, V. Gibbi. 2008.

Behavioural, physiological, neuroendocrine and molecular responses to heat stress. Poult Prod hot Clim. p. 49-69.

Fadilah, R. dan Fathkuroji. 2013. Memaksimalkan Produksi Ayam Ras Petelur. Agromedia Pustaka. Jakarta.

Frandson, R. D. 1993. Anatomi dan Fisiologi Ternak. Gadjah Mada University Press. Yogyakarta.

Gous, R. M. 2010. Nutritional limitations on growth and development in poultry. Livestock Science 130(3): 25--32.

Hilman, P.E., N. R. Scot, dan V. A. Tienhove. 1985. Physiological Responses and Adaptations to Hot and Cold Environments, In: Yousef, M.K. (Ed.) Stress Physiology in Livestock. CRC Press Inc. Boca Raton. Florida.

Lin, H., H. F. Zhang, R. Du, X. H. Gu, Z. Y. Zhang, J. Buyse and E. Decuypere. 2005. Thermoregulation responses of broiler chickens to humidity at different ambient temperatures. ii. four weeks of age. Poultry Science. 84:1173--1178.

McDowell. 1972. Improvement of Livestock Production in Warm Climate. W.H. Freemanand Co. San Frascisco. P 1--128.

Mushawwir, A dan D. Latipudin. 2011. Respon fisiologi thermoregulasi ayam ras petelur fase grower dan layer. Jurnal Fakultas Peternakan. Universitas Diponegoro. Semarang.

Mutaf, S., N. Ş. Kahraman, and M. Z. Firat. 2008. Surface wetting and its effect on body and surface temperatures of domestic laying hens at different thermal conditions. Poultry Science 87:2441-2450.

Ozkan, S. dan Bayram. A. 2010. Effects of a 16hour light, 8-hour dark lighting schedule on behavioral traits and performace in male broiler chickens. Journal of Poultry Science. 19:263--273.

Paliadi, T. Widjastuti, A. Mushawwir. 2015. Thermoregulasi dan Hen Day Production Ayam Petelur Fase Layer pada Temperature Humidity Index yang Berbeda. Universitas Padjadjaran. Bandung.

Priyatno. 2004. Membuat Kandang Ayam cetakan ke-8. Penebar Swadaya. Jakarta.
Sohail, M. U., A. Ijaz, M. S. Yousaf, K. Ashraf, T. Yaqub, H. Zaneb, M. Aleem, and H. Rehman. 2010. Alleviation of cyclic heat stress in broilers by dietary suplementation of mannanoligosaccharide and lactobacillus-based probiotic: dynamics of cortisol, thyroid hormones, cholesterol, c-reactive protein, and humoral immunity. Poult. Sci. 89:1934--1938.

Suharyati, S., M. Hartono, dan P. E. Santosa. 2017. Buku Ajar Dasar Reproduksi Ternak. Aura Publishing. Bandarlampung.

Swenson. M. O. 1997. Dukes Physiology of Domestic Animal: Second Edition. Comstok Publishing Associates a division. Cornell University Press.

Tamzil, M.H., R. R. Noor, P. S. Hardjosworo, W. Manalu, dan C. Sumantri. 2013. Keragaman gen heat shok protein 70 ayam kampung, ayam arab, dan ayam ras. Jurnal Veteriner. 14:317--326.

Virden, W.S. dan M. T. Kidd. 2009. Physiological stress in broilers: ramifications on nutrient digestibility and responses. J. Appl Poult Res. 18:338-347.

Yahav, S., M. Rusal, and D. Shinder. 2008. The effect of ventilation on performance body and surface temperature of young turkeys. Poultry Science. 87:133--137.

Yanagi, T. Jr., H. Xin, and R. S. Gates. 2002. Optimization of partial surface wetting to cool caged laying hens. Appl. Eng. Agric. 45:1091--1100.

Yousef, M. K. 1985. Stress Physiology in Livestock Basic Principles. Vol 1.CRC Press Inc. Boca Raton. Florida. 